\title{
Jurnal Ekobistek
}

https://jman-upiyptk.org/ojs

\section{Penguasaan Pasar dan Daya Tawar Palem Waregu (Raphis Excelsa) Sumatera Barat pada Pemasaran dalam Daerah dan Internasional}

\author{
Esa Diya Wahyuni ${ }^{\circledR}$ \\ Universitas Ekasakti Padang \\ esa_diya@yahoo.co.id
}

\begin{abstract}
This study aims to determine the market dominance and bargaining power of West Sumatra Palm Waregu (Raphis Excelsa ) in local and international marketing. This research was conducted using a qualitative descriptive method on a case study of five farmer groups that cultivate Raphis Excelsa in monoculture in West Sumatra. Qualitative descriptive analysis of the case study is discussed in accordance with the research objectives. The results of the research are market control, namely the ability to influence the market, market behavior or marketing which includes price, demand, flow of goods, quality of goods, and marketing functions. Market control based on price indicators for marketing within the region is better than abroad. Market control based on demand indicators for domestic and foreign marketing has been fulfilled by West Sumatra. Market control on plant distribution indicators for domestic and foreign marketing has been running effectively. Market control based on goods quality indicators for local marketing has been fulfilled while for foreign marketing it has not been fulfilled. Market control for marketing function indicators is quite good because most of the components in this function have been fulfilled by Raphis Excelsa West Sumatra. However, the marketing of Raphis Excelsa is still constrained by the standardization function which requires Raphis Excelsa plants to be free from pests and diseases. The bargaining power of Raphis Excelsa for local marketing is relatively strong compared to the bargaining power of foreign/international marketing.
\end{abstract}

Keywords: Market Control, Bargaining Power, Goods Quality, Standardization, Palm Waregu.

\begin{abstract}
Abstrak
Penelitian ini bertujuan untuk mengetahui penguasaan pasar dan daya tawar Palem Waregu (Raphis Excelsa) Sumatera Barat pada pemasaran dalam daerah dan internasional. Penelitian ini dilakukan dengan metode deskriptif kualitatif terhadap study kasus pada lima kelompok tani yang mengusahakan Raphis Excelsa secara monokultur di Sumatera Barat. Analisis deskriptif kualitatif terhadap study kasus dibahas sesuai dengan tujuan penelitian. Hasil penelitian berupa penguasaan pasar yaitu kemampuan untuk mempengaruhi pasar, tingkah laku pasar atau pemasaran yang meliputi harga, permintaan, arus barang, kualitas barang, dan fungsi pemasaran. Penguasaan pasar berdasarkan indikator harga untuk pemasaran dalam daerah lebih baik daripada luar negeri. Penguasaan pasar berdasarkan indikator permintaan untuk pemasaran dalam daerah dan luar negeri sudah terpenuhi oleh Sumatera Barat. Penguasaan pasar pada indikator penyaluran tanaman untuk pemasaran dalam daerah dan luar negeri sudah berjalan efektif. Penguasaan pasar berdasarkan indikator kualitas barang untuk pemasaran dalam daerah sudah terpenuhi sedangkan untuk pemasaran luar negeri belum terpenuhi. Penguasaan pasar untuk indikator fungsi pemasaran sudah cukup baik karena sebagian besar komponen dalam fungsi tersebut telah terpenuhi oleh Raphis Excelsa Sumatera Barat. Namun, pemasaran Raphis exselsa masih terkandala pada fungsi standarisasi yang mengharuskan tanaman Raphis Excelsa bebas dari hama penyakit. Daya tawar pada Raphis Excelsa untuk pemasaran dalam daerah relatif kuat dibandingkan dengan daya tawar pada pemasaran luar negeri / internasional.
\end{abstract}

Kata kunci: Penguasaan Pasar, Daya Tawar, Kualitas Barang, Standarisasi, Palem Waregu.

(C) 2021 EKOBISTEK

\section{Pendahuluan}

Sektor pertanian secara umum terdiri dari tanaman pangan, tanaman perkebunan dan tanaman hortikultura. Indonesia yang dikenal sebagai salah satu pusat Tanaman hortikultura terdiri dari komoditi buah- keanekaragaman hayati mempunyai kekayaan flora buahan, sayuran, biofarmaka dan tanaman hias. yang melimpah dan sebagian berpotensi sebagai Masing-masing komoditi memberikan kontribusi bagi tanaman hias. Dengan berbagai ragam keindahan dan perekonomian nasional yang ditunjukan melalui keunikan, flora Indonesia mempunyai peluang untuk perolehan nilai Produk Domestik Bruto (PDB). Pada diberdayakan sebagai komoditas komersial yang tahun 2008 komoditi buahbuahan berkontribusi penting dan dapat memberikan kontribusi dalam terhadap PDB sebesar 0,7 persen, sayuran 7,2 persen, peningkatan pendapatan petani tanaman hias dan devisa biofarmaka 0,3 persen dan tanaman hias 7,1 persen. Negara [2]. Perkembangan bisnis tanaman hias yang Berdasarkan nilai PDB, tanaman hias yang merupakan begitu pesat utamanya disebabkan karena sektor ini salah satu komoditi hortikultura memberikan kontribusi sangat mudah ditekuni dan memiliki nilai ekonomi yang cukup tinggi. Menurut pendapat pakar tanaman, 
nilai ekonomis tanaman hias utamanya ditentukan oleh Ekspor perdana tersebut adalah sebanyak 1.700 pola daun, warna daun, jenis tanaman, dan keunikan rangkaian untuk satu kontainer ke negara Belanda [6]. tanaman.

Daerah yang menjadi sentra pengembangan Raphis Permintaan tanaman hias di pasar dunia cenderung Excelsa di Sumatera Barat adalah Kota Padang, Kota terus meningkat dari tahun ke tahun demikian juga Padang Panjang, Kota Bukittinggi, Kota Payakumbuh permintaan akan produk tanaman hias tropis cenderung dan Kabupaten Agam. Ekspor 2008 tersebut diambil terus meningkat. Produsen tanaman hias tropis dari tiga sentra produksi dari Kota Padang, Kota jumlahnya masih relatif terbatas, dan Indonesia sebagai Padang Panjang, dan Kota Bukittinggi. Selain untuk negara tropis yang memiliki keunggulan sumberdaya memenuhi permintaan dari luar negeri, Raphis Excelsa alam yang cukup dipandang mampu melakukan juga di pasarkan di dalam daerah Sumatera Barat dan penetrasi pasar internasional tanaman tropis. Produksi ke luar daerah Sumatera Barat yaitu di Provinsi Jambi. tanaman hias Indonesia tumbuh secara mengesankan Selanjutnya, pada maret 2012 ini juga dilakukan ekspor dalam beberapa tahun terakhir dan telah memberikan Raphis Excelsa kedua dengan PT. Agro21 Gemilang. kontribusi pada PDB yang juga meningkat setiap tahun. Adapun persyaratan untuk ekspor tersebut adalah Pada tahun 2000 kontribusi pada PDB mencapai Rp 2,8 Tanaman bebas dari hama penyakit, bentuk rangkaian trilyun dan menjadi Rp 4,6 trilyun pada tahun 2004 tanaman asimetris, dan tinggi ideal tanaman 40 s.d 50 serta diperkirakan akan menjadi Rp 7,7 trilyun pada $\mathrm{cm}$. Kendala di lapangan adalah adanya hama penyakit tahun 2008 dengan laju pertumbuhan sebesar 13,6\% pada aspek budidaya berupa tangkai daun panjang, kutu per tahun [4].

Palem Waregu (Raphis Excelsa) sebagai salah satu dari kedua Palmaceae umumnya digunakan sebagai tanaman hias ruangan atau tanaman taman. Karena tanaman ini memiliki sosok gagah, angun, indah, mudah merawatnya, nuansa khas tumbuhan tropis, dan tahan terhadap perubahan cuaca. Tanaman ini dapat tumbuh dengan baik dan memiliki peluang ekspor cukup besar ke pasar Eropa terutama Belanda. Selain telah dibudidayakan di Jawa, sejak tahun 2008 telah dikembangkan di Provinsi Riau, dan Sumatera Barat sebagai gerbang ekspor. Sebagai negara pesaing adalah Vietnam dan Malaysia [5].

putih, dan embun jelaga dimana daun menghitam. Hal ini dapat menyebabkan harga jual Raphis Excelsa menjadi rendah dan belum dapat bersaing dengan Raphis Excelsa dari negara lainnya. Berdasarkan kelemahan ini maka perlu diketahui bagaimana penguasaan pasar dan daya tawar Raphis Excelsa Sumatera Barat pada pemasaran dalam daerah dan internasional. Penelitian ini bertujuan untuk mengetahui penguasaan pasar palem waregu (Raphis Excelsa ) Sumatera Barat pada pemasaran dalam daerah dan internasional serta untuk mengetahui daya tawar palem waregu (Raphis Excelsa) Sumatera Barat pada pemasaran dalam daerah dan internasional. Penulisan artikel ini bermanfaat bagi para pembaca Tanaman tropis Raphis Excelsa dari Indonesia di untuk mengetahui penguasaan pasar dan daya tawar ekspor ke Belanda. Pasar terbesar adalah Inggris dan Raphis Excelsa dari Sumatera Barat pada pemasaran Jerman, hanya saja eksportir Indonesia belum mampu dalam daerah dan internasional. Juga menambah menembusnya. Indonesia merupakan negara produsen inspirasi bagi pembaca dalam berbisnis atau utama komoditi ini dengan negara peasing antara lain mengusahakan usaha tanaman hias Raphis Excelsa .

Vietnam dan Malaysia. Eksportir Raphis Excelsa masih sangat terbatas, hanya 5 perusahaan yaitu PT. Agro21 Gemilang, PT. Benara, PT. Tropical Greeneries, PT. Inti matahari, dan CV. ASA Indonesia. Mereka masih sangat tergantung pada pasokan dari para pengumpul yang mengumpulkan tanaman dari sekitar perumahan penduduk dengan luas yang sangat terbatas dan perawatan tidak intensif. Kondisi seperti ini menyebabkan keterbatasan dalam memenuhi quota ekspor, baik jumlah, kontinuitas dan kualitas.Untuk menambah kemampuan memasok pasar global, Direktorat Jenderal Hortikultura mulai tahun 2008 mengembangkan sentra baru di Sumatera Barat (Padang, Padang Panjang, Bukit Tinggi), Riau (Pakanbaru), dan Kepri (Batam dan Bintan) [6].

Sumatera Barat memulai budidaya Raphis Excelsa sejak tahun 2008 dengan ekspor perdana pada Januari 2010 melalui PT. Agro Gemilang di Riau. Ekspor perdana tersebut dalam bentuk rangkaian dalam pot.

Penetapan harga berfungsi untuk menguasai pasar (Market Skiming Pricing), beberapa perusahaan ingin memaksilmalkan unit perusahaan. Mereka percaya bahwa volume penjualan yang lebih tinggi akan menghasilakan biaya per unit yang lebih rendah dan laba jangka panjang yang lebih tinggi. Mereka menetapkan harga terendah dengan berasumsi bahwa pasar peka terhadap harga. Banyak perusahaan yang menyukai penetapan harga tinggi untuk menskim pasar. Perusahaan menetapkan harga yang lebih layak bagi beberapa segmen pasar untuk menerima produk baru. Tiap kali penjualan mulai menurun, maka produk baru tersebut diturunkan harganya untuk menarik lapisan pelanggan yang peka terhadap harga. Dengan cara itu maka pendapatan maksimum didapat dari beberapa segmen pasar.

Penguasaan pasar merupakan penguasaan pasar terhadap proses, cara, atau perbuatan menguasai pasar. Dalam penguasaan pasar disini adalah menguasai dari hulu ke hilir yang mana pada tiap tahapan dikuasai oleh

Jurnal Ekobistek Vol.20 No. 3 (2021) 156-161 
pelaku usaha yang sama yang memiliki hubungan serendah mungkin, sementara penjual akan selalu dengan keuntungan yang akan didapatkan oleh berusaha menjual dengan harga setinggi mungkin. perusahaan lebih besar dalam satu pasar bersangkutan Kekuatan tawar-menawar adalah salah satu dari banyak terhadap satu barang atau jasa tertentu. Penguasaan konsep ekonomi yang diperkenalkan untuk pasar hanya terhadap satu pelaku usaha, maka ia akan memfasilitasi pemahaman tentang semua faktor dengan mudah menetapkan harga pasar pada pasar berbeda yang dapat memengaruhi bagaimana bersangkutan dan akan menimbulkan ketergantungan kesepakatan dibuat dan bagaimana kinerja bisnis.

konsumen pada produk karena sulitnya mendapatkan produk yang sama dengan kualitas yang sama karena adanya penguasan pasar dapat menghalangi pelaku usaha lain masuk ke dalam pasar dan terbatasnya produk pada pasar [7].

Derajat penguasaan pasar oleh perusahaan - perusahaan industri yang berada di dalam pasar merupakan sebuah situasi dalam konsentrasi pasar. Semakin tinggi tingkat konsentrasi pasar maka akan meningkatkan kemampuan perusahaan atau pedagang yang ada di dalam pasar [8]. Hal ini bertujuan untuk dapat menekan persaingan pasar sehingga dapat meningkatkan peluang mereka untuk dapat menentukan harga yang tinggi dan memaksimalkan keuntungannya.

Konsentrasi penguasaan pasar suatu industri selalu terkait dengan pembahasan mengenai struktur pasar [9]. Jumlah dan ukuran perusahaan adalah faktor penting yang menentukan struktur pasar, dimana jumlah dan ukuran pasar tersebut akan menentukan tingkat konsentrasi dalam sebuah industri. Pada ukuran pasar terdiri dari jumlah penjual dan ukuran perusahaan dimana jumlah penjual adalah faktor yang paling penting dalam menentukan kekuasaan. Dalam pasar persaingan sempurna terdapat banyak penjual. Menurut pengertian secara relatif, dimana dengan banyaknya penjual mengakibatkan mereka tidak memiliki kekuasaan pasar. Jumlah penjual akan mempengaruhi perilaku karena jumlah akan mempengaruhi ekspektasi tiap perusahaan terhadap perilaku pesaingnya. Sementara itu, untuk ukuran perusahaan (pangsa pasar I market share) merupakan perbandingan antara hasil penjualan suatu perusahaan dengan total penjualan industri. Pangsa pasar menggambarkan struktur pasar yang relatif lebih baik dibandingkan dengan hanya melihat jumlah perusahaan yang bersaing di dalam industri yang bersangkutan. Elemen ini merupakan indikator dalam menentukan tingkat kekuasaan pasar (market power) suatu perusahaan. Semakin tinggi pangsa pasarnya, maka semakin tinggi pula kekuasaan pasar yang dimiliki.

Bargaining power atau daya tawar adalah ukuran kapasitas satu pihak untuk mempengaruhi pihak lain [10]. Poin penting dalam negosiasi adanya pihak-pihak dengan daya tawar yang lebih tinggi dapat memanfaatkan keadaan mereka untuk mencapai kesepakatan yang lebih diinginkan dengan pihak lain. Menegosiasikan persyaratan kesepakatan apa pun, formal maupun tidak, adalah sebuah permasalahan yang rumit. Dengan mengambil contoh perdagangan, pembeli akan selalu ingin bernegosiasi dengan harga

Faktor-faktor yang mempengaruhi daya tawar [10] adalah:

a. Memiliki alternatif, yaitu salah satu pihak tidak perlu berurusan dengan pihak lain, karena mereka memiliki alternatif, maka mereka memiliki bargaining power yang lebih besar. Ini karena mereka menghadirkan risiko karena dapat meninggalkan kesepakatan tanpa menyebabkan terlalu banyak masalah bagi diri mereka sendiri. Jika salah satu pihak tidak memiliki alternatif, maka mereka memiliki sedikit daya tawar karena negosiator lain dapat mengancam untuk meninggalkan kesepakatan, meninggalkan mereka dalam situasi yang tidak menguntungkan.

b. Mudah beralih ke alternatif lain, yaitu suatu pihak yang memiliki daya tawar yang lebih besar jika ada sedikit masalah di dalamnya akan mudah beralih ke alternatif lain, dan sebaliknya.

c. Kurangnya kebutuhan / kepentingan, yaitu salah satu pihak dalam negosiasi dapat meninggalkan kesepakatan tanpa mengalami konsekuensi apa pun, baik karena kurangnya kebutuhan atau kepentingan untuk menghentikan kesepakatan, maka mereka memiliki daya tawar yang lebih besar. Secara tidak langsung mengancam pihak lain dengan kehilangan bisnis, sehingga mereka harus menawarkan 'tawarmenawar' yang lebih baik.

d.Pengetahuan yang relevan, yaitu memiliki pengetahuan di bidang yang relevan juga memberikan daya tawar yang lebih besar kepada para pihak. Ini karena mereka kurang rentan untuk membuat kesepakatan yang tidak menguntungkan karena kurang informasi atau informasi yang salah".

Daya tawar pembeli pada industri berperan dalam menekan harga untuk turun, serta memberikan penawaran dalam peningkatan kualitas ataupun layanan yang lebih, dan membuat kompetitor saling bersaing satu sama lain [11]. Lima kekuatan persaingan sebagai alat untuk menganalisis lingkungan persaingan industri. Lima kekuatan persaingan tersebut adalah ancaman pendatang baru; kekuatan tawar menawar pemasok; kekuatan tawar menawar pembeli; ancaman produk subtitusi; persaingan di dalam industri. Lima kekuatan tersebut secara bersama-sama menentukan intensitas persaingan dan kemampuan dalam sebuah industry".

Jurnal Ekobistek Vol.20 No. 3 (2021) 156-161 


\section{Metodologi Penelitian}

Dalam penulisan ini, pembahasan dilakukan dengan metode deskriptif kualitatif terhadap study kasus pada lima kelompok tani yang mengusahakan Raphis Excelsa secara monokultur di Sumatera Barat. Untuk mengetahui penguasaan pasar Sumatera Barat pada pemasaran dalam daerah dan internasional (tujuan pertama) maka aspek yang dibahas secara deskriptif adalah mengenai harga, permintaan, arus barang, kualitas barang, dan fungsi pemasaran. Sedangkan untuk mengetahui daya tawar Sumatera Barat pada pemasaran dalam daerah dan internasional aspek yang dibahas secara deskriptif adalah mengenai kemampuan relatif pembeli dan penjual mempengaruhi harga dalam transaksi.

Lima kelompok tani yang menjadi objek dalam penelitian ini yaitu:

a. Asosiasi Raphis Kota Padang yang berlokasi di Kelurahan Lubuk Minturun, Kecamatan Koto Tangah, Kota Padang.

b. Kelompok tani Anyelir di Kelurahan Bukit Apit Puhun, Kecamatan Guguk Panjang, Kota Bukittinggi.

c. Kelompok tani Subur Makmur di Nagari Lambah, Kecamatan IV Angkat, Kabupaten Agam.

d. Kelompok tani Ademas di Kelurahan Koto Tangah, Kecamatan Payakumbuh Barat.

e. Asosiasi Raphis Kota Padang Panjang, Kelurahan Ganting, Kecamatan Padang Panjang Timur, Kota Padang Panjang.

Selanjutnya, analisis deskriptif kualitatif terhadap study kasus dibahas sesuai dengan tujuan penelitian.

\section{Hasil Dan Pembahasan}

Penguasaan pasar Raphis Excelsa Sumatera Barat pada 6 pemasaran dalam daerah dan internasional adalah 7 menguasai usaha dari hulu ke hilir pada pemasaran dalam daerah dan internasional yang mana pada tiap tahapan usaha. Pelaku usaha Raphis yang sama dan memiliki hubungan kelembagaan kelompok tani dan Berdasarkan Tabel 1 bahwa harga Raphis Excelsa dibawah binaan Dinas Tanaman Pangan dan untuk pemasaran dalam negeri lebih besar dari harga Hortikultura ropinsi Sumatera Barat. Berdasarkan Raphis Excelsa untuk pemasaran di luar negeri. keuntungan yang akan didapatkan oleh kelompok tani Penguasaan pasar berdasarkan indikator harga untuk menjadi lebih besar terhadap pasar tanaman hias pemasaran dalam daerah lebih baik dari pada luar Raphis Excelsa. Penguasaan pasar hanya terhadap satu negeri.

pelaku usaha yaitu lima kelompok tani yang 3.1. Permintaan mengusahakan Raphis Excelsa secara monokultur di

Sumatera Barat. Setiap kelompok dapat menetapkan Permintaan Raphis Excelsa dari dalam daerah dan luar harga pasar pada pasar bersangkutan dan akan negeri sudah dapat dipenuhi oleh produksi Raphis menimbulkan ketergantungan konsumen pada produk Excelsa di Sumatera Barat. Jumlah produksi tanaman karena sulitnya mendapatkan produk yang sama dengan ini di Kota Padang adalah 124.975 batang, Kota kualitas yang sama. Dengan adanya penguasan pasar Bukittinggi 118.000 batang, Kabupaten Agam 89.400 Raphis Excelsa oleh kelompok tani di Sumatera Barat batang, Kota Payakumbuh 63.760 batang, dan Kota maka dapat menghalangi pelaku usaha lain masuk ke Padang Panjang 57.519 batang [6]. Berarti penguasaan 
pasar berdasarkan indikator permintaan untuk Pembiaayan dilakukan oleh BANSOS (Bantuan Sosial) pemasaran dalam daerah dan luar negeri sudah dari Departemen Pertanian untuk budidaya dan terpenuhi oleh Sumatera Barat.

pemasaran. Selain itu, penanggungan resiko juga sudah ditanggung oleh Dinas Pertanian terkait. Jika ekspor gagal maka seluruh biaya kerugian dibayarkan oleh

\subsection{Arus Barang} Arus barang atau penyaluran tanaman untuk pemasaran Dinas Pertanian Tanaman Pangan dan Hortikultura
dalam daerah meliputi petani ke pasar lokal; petani ke Propinsi Sumatera Barat. Informasi pasar juga sudah nursery ke konsumen rental; dan petani ke nursery ke dimiliki oleh Dinas Pertanian Tanaman Pangan dan pasar lokal ke konsumen rental. Pemasaran luar negeri Hortikultura Propinsi Sumatera Barat. Melaui dinas dimulai dari petani ke nursery ke main nursery ke tersebut maka informasi harga terbaru dan pasar baru minang agrogemilang ke importir luar negeri. dapat diketahui oleh kelompok tani.

Penguasaan pasar pada indikator penyaluran tanaman untuk pemasaran dalam daerah dan luar negeri sudah berjalan efektif.

\subsection{Kualitas Barang}

Kualitas barang atau kualitas tanaman masih menjadi permasalahan pada agribisnis. Kualitas mutu masih terkendala pada permasalahan budidaya. Komponen permasalahan terdapat pada tangkai daun panjang, kutu putih, dan embun jelaga. Komponen ini mempengaruhi harga jual tanaman bahkan dapat mengagalkan ekspor. Persyaratan kualitas komponen tanaman belum terpenuhi oleh produsen (petani). Pada pemasaran dalam daerah, hal ini tidak menjadi permasalahan karena konsumen biasanya membeli atau merental tanaman dalam jumlah yang sedikit sehingga dapat memilih tanaman yang berkualitas bagus. Penguasaan pasar berdasarkan indikator kualitas barang untuk pemasaran dalam daerah sudah terpenuhi sedangkan untuk pemasaran luar negeri belum terpenuhi.

\subsection{Fungsi Pemasaran}

Penguasaan pasar untuk indikator fungsi pemasaran sudah cukup baik karena sebagian besar komponen dalam fungsi tersebut telah terpenuhi. Kendala dalam pemasaran masih terdapat pada fungsi standarisasi yang mengharuskan tanaman bebas dari hama penyakit. Untuk mengatasi ini diperlukan varietas tanaman yang tahan terhadap hama penyakit dan pemeliharaan yang intensif. Aspek tekhnologi pemuliaan tanaman perlu diperhatikan oleh pemerintah dalam menciptakan varietas yang unggul dan tahan penyakit. Kegiatan penyuluhan tentang pemeliharaan yang intensif juga diperlukan untuk menciptakan kualitas tanaman yang prima sehingga dapat bersaing dalam perdagangan dalam daerah dan internasional.

Daya tawar (bargaining power) adalah kemampuan relatif pembeli dan penjual biaya, berubahnya biaya fungsi tataniaga, tataniaga menjadi tidak efisien. Penguasaan pasar yang rendah dapat mempengaruhi daya tawar produk tanaman hias pada pemasaran dalam daerah dan luar negeri (internasional). Pemerintah selaku pelindung dan pengambil kebijakan pertanian Fungsi pemasaran meliputi petukaran, yaitu pembelian perlu memperkuat penguasaan pasar petani melalui dan penjualan; pengadaan atau penyediaan, yaitu indikator penguasaan harga, permintaan, arus barang, penyimpanan (storage) dan transportasi; pemberian kualitas barang, dan fungsi pemasaran. Hasil penelitian fasilitas, yaitu standarisasi, pembiayaan (financing), penanggungan resiko dan informasi pasar [13].

Fungsi pertukaran untuk pembelian dan penjualan sudah dimiliki oleh pemasaran Raphis Excelsa ini. Dimulai dari pembelian bibit tanaman ke daerah Jawa, dibudidayakan pada sentra produksi di Sumatera Barat, dan selanjutnya dijual untuk kebutuhan dalam daerah dan luar negeri. Fungsi pengadaan atau penyediaan juga telah dipenuhi oleh pemasaran Raphis Excelsa ini. Tanaman yang telah diproduksi dipelihara dalam main nursery untuk selanjutnya dipasarkan ke luar negeri. Dalam proses pengankutan/transportasi Raphis disimpan dalam container atau pendingin agar tanaman tidak layu atau tetap fresh selama dalam perjalanan sampai ke tangan konsumen. Fungsi pemberian fasilitas berupa standarisari sudah diberikan oleh dinas pertanian terkait, namun standarisari untuk pemasaran luar negeri belum terpenuhi oleh Sumatera Barat karena terkendala tangkai daun panjang dan hama penyakit. ini untuk meningkatkan daya tawar ke luar negeri harus diperlukan pembenahan terhadap aspek tekhnologi pemuliaan tanaman, budidaya, dan pemeliharaan tanaman.

\section{Kesimpulan}

Penguasaan pasar adalah kemampuan untuk mempengaruhi pasar, tingkah laku pasar atau pemasaran yang meliputi harga, permintaan, arus barang, kualitas barang, dan fungsi pemasaran. Penguasaan pasar berdasarkan indikator harga untuk pemasaran dalam daerah lebih baik daripada luar negeri. Penguasaan pasar berdasarkan indikator permintaan untuk pemasaran dalam daerah dan luar negeri sudah terpenuhi oleh Sumatera Barat. Penguasaan pasar pada indikator penyaluran tanaman untuk pemasaran dalam daerah dan luar negeri sudah berjalan efektif. Penguasaan pasar berdasarkan indikator kualitas barang untuk pemasaran dalam daerah sudah terpenuhi sedangkan untuk pemasaran luar negeri belum terpenuhi. Penguasaan pasar untuk indikator fungsi pemasaran sudah cukup baik karena 
sebagian besar komponen dalam fungsi tersebut telah terpenuhi. Kendala pemasaran terdapat pada fungsi standarisasi yang mengharuskan tanaman yang bebas dari hama penyakit. Daya tawar untuk pemasaran dalam daerah relatif kuat dibandingkan dengan daya tawar pada pemasaran luar negeri (internasional).

\section{Daftar Rujukan}

[1] Hapsari, D. T. (2011). Analisis Strategi Pemasaran Tanaman Hias pada PT. Godong Ijo Nursery Sawangan Kota Depok, Jawa Barat. Skripsi. Institut Pertanian Bogor. Bogor.

[2] Balai Penelitian Tanaman Hias (2011). Kementrian Pertanian RI.

[3] Sari, D. M. (2007). Analisis Perilaku Konsumen Terhadap Keputusan Pembelian Tanaman Hias di Pasar Nangka Surakarta. Skripsi. Universitas Muhammadyah Surakarta. Surakarta.

[4] Anonimus (2010). http://www.agromaret.com.

[5] Kementrian Pertanian. 2010. http://www.kementan.go.id

[6] Dinas Pertanian dan Tanaman Pangan dan Hortikultura Propinsi Sumatera Barat (2011).

[7] Haryanti, S. (2016). Analisis Yuridis Terhadap Praktek Diskriminasi Penerapan Tarif Multiguna PT PLN (Persero) dalam Jasa Penyediaan Tenaga Listrik untuk Pelanggan Bisnis dan Industri Menurut Undang-Undang Nomor 5 Tahun 1999 Tentang Larangan Praktek Monopoli dan Persaingan Usaha Tidak Sehat (Studi Kasus Putusan KPPU No.06/KPPU-I/2011). Perpustakaan-Universitas Trisakti. Jakarta.

[8] Manalu, D. S. T. (2019). Analisis Struktur Pasar Kentang Granola di Kecamatan Batur, Kabupaten Banjarnegara, Jawa Tengah. Jurnal Sosial dan Ekonomi Pertanian, 13(1): 15 - 24.

[9] Agustrai (2018). Analisis Konsentrasi Penguasaan Pasar dan Relasi Harga antara Petani dengan Pedagang Pengumpul Cengkeh di Kabupaten Balukumba. Tesis Sekolah Pascasarjana. Universitas Hasanudin. Makasar.

[10]Priharto, S. (2020). Mengetahui Pentingnya Bargaining Power dalam Sebuah Bisnis. https://accurate.id (diakses tanggal 24 Juni. 2021).

[11]Manimabi, Priyanto, R. \& Nadapdap, H. J. (2018). Daya Kekuatan Tawar Menawar Pengusaha Slondok di Desa Sumurarum Kecamatan Grabag Kabupaten Magelang. Agrisocionomics. Jurnal Sosial Ekonomi Pertanian, 2(1): 58-69.

[12]Dinas Pertanian dan Tanaman Pangan dan Hortikultura Propinsi Sumatera Barat (2012)

[13] Kohls, R. L., \& Uhl, J. N. (2002). Marketing of Agricultural Products (Ninth Edition ed.). Prentice Hall (CHAPTER 15). New Jersey. 